\title{
Effects of Water Stress at Different Growth Stages on Greenhouse Tomato Yield and Quality
}

\author{
Molla Md. Nuruddin', Chandra A. Madramootoo², and \\ Georges T. Dodds ${ }^{3}$ \\ Department of Bioresource Engineering, Faculty of Agricultural and \\ Environmental Sciences, Macdonald Campus of McGill University, 21111 \\ Lakeshore Road, Montreal, QC, Canada, H9X 3 V9
}

Additional index words. deficit irrigation, marketable yield, water use efficiency, fruit quality, Lycopersicon esculentum

\begin{abstract}
Tomatoes (Lycopersicon esculentum Mill.cv. Sunstart) were grown in a greenhouse during Summer 1999 and again in Winter 2000. Two available soil water (ASW) deficit thresholds, $65 \%$ and $80 \%$, at which plants were irrigated to field capacity were factorially combined with five irrigation timing patterns: 1) no water stress; 2) stress throughout the entire growing season; 3) stress during first cluster flowering and fruit set 4) stress during first cluster fruit growth; and 5) stress during first cluster fruit ripening. Crop yields, water use efficiency, as well as maximum and minimum equatorial fruit diameters and fruit height were measured. Quality parameters of soluble solids, $\mathrm{pH}$, and fruit color were also measured. Water stress throughout the growing season significantly reduced yield and fruit size, but plants stressed only during flowering showed fewer but bigger fruit than completely non-stressed plants. Consequently, on a weight basis the stressed at flowering and nonstressed plants had similar yields. Nonstressed and flowering-stressed fruit showed lower soluble solids and a lighter color of red ripe fruit than the other stress treatments. No significant differences in yield or quality were found between the two stress levels $(65 \%$ vs. $80 \%$ ASW depletion before irrigation). Water stress only during flowering resulted in better yields and quality than stress at other specific developmental stages or at all times, but equal or poorer yields and water use efficiency than nonstressed plants.
\end{abstract}

A growing scarcity of water relative to human demand occurs in many parts of the world, but appropriate water management practices can help ensure the survival and sustainability of agricultural and economic activities related to water (Postel, 2000). Water deficits and insufficient water are the main limiting factors affecting worldwide crop production. Deficit irrigation (DI) can reduce production costs, conserve water and minimize leaching of nutrients and pesticides into ground water. While this has primarily been a concern in field crops, the disposal of nutrient and pesticide-laden waters from large greenhouse complexes has come under scrutiny. Establishing DI as a management tool for tomatoes could be very effective in situations where water is scarce and also for reducing effluent contamination. This is especially important since tomato is a popular greenhouse-grown vegetable, grown extensively throughout the world.

However, before DI can be adopted as a

Received for publication. Accepted for publication. We dedicate this paper to the memory of Pamela M. Ludford, professor of Vegetable Crops, Cornell Univ. We acknowledge the financial support of the International Council for Canadian Studies to $\mathrm{M}$. Nuruddin. We thank R. Smith, greenhouse manager and E. Noroozi for help with fruit quality assessments. ${ }^{1}$ Graduate Student.

${ }^{2}$ Professor.

${ }^{3}$ Research Associate. To whom reprint requests should be addressed. Phone:(514)398-8785, Fax:(514)398 8387; e-mail: dodds@macdonald.mcgill.ca management tool, its effect on fruit yield and quality should be examined (Kirda, 2002). Measurements of pan evaporation, soil moisture content, or simulations of the soil water balance (Hoffman et al., 1990), have been used to estimate irrigation requirements both in terms of timing and quantity (Heermann et al., 1990). However, not all stages of development are equally sensitive to soil moisture deficits; for example, the flowering and fruit setting stages of tomato have long been known to be the most sensitive to water deficits in terms of yield (Salter, 1954). Lower or deficitary irrigation rates generally decrease yield and fruit size (Giardini et al., 1988), therefore, if deficit irrigation is applied for fresh market greenhouse production to limit costs and potential pollution, one is faced with the prospect of also reducing yield. Consequently, a judicious application of irrigation water is necessary.

With this in view, the response of tomato to both quantitative and temporal variations in soil moisture was studied, and the viability of deficit irrigation was assessed. Along with appropriate controls, two quantitative levels of water stress were combined with three growth stages at which the stress was applied, and tomato yield and fruit quality were assessed.

\section{Materials and Methods}

Experimental setup. The influence of different irrigation regimes on the production and quality of greenhouse tomatoes was studied during Summer 1999 and again in Winter 2000. In both years, identical experiments were set up in the Macdonald Campus greenhouse of McGill Univ. in Montreal, Quebec. Two available soil water (ASW) deficit levels, $65 \%$ and $80 \%$, at which irrigation up to field capacity was implemented were factorially combined with five irrigation timing patterns: (1) no stress (NS); (2-4) stress during flowering and fruit set $(\mathrm{F})$, fruit growth $(\mathrm{G})$, or fruit ripening $(\mathrm{R})$ of the first cluster; and (5) stress from flowering through ripening of the first cluster (FGR), in a randomized completeblock design with four replicates. This resulted in nine treatments, as the "NS" controls for both $65 \%$ and $80 \%$ ASW were identical and hence reduced to a single treatment.

Plants were grown in 24-cm-high polyethylene pots that had an upper diameter of $28 \mathrm{~cm}$ and a diameter of $22 \mathrm{~cm}$ at the base, and a mean inner diameter of $24.5 \mathrm{~cm}$ in the portion containing soil (soil volume of roughly $9.6 \mathrm{~L} / \mathrm{pot}$ ). Each pot was placed in a $55 \times$ $28.5 \times 7-\mathrm{cm}$ white plastic seedling tray on the concrete floor of the greenhouse, in order to trap any irrigation overflow or soil material escaping from the drainage holes at the base of the pots. Plants were spaced $60 \mathrm{~cm}$ apart both within and between rows. Natural lighting was supplemented with overhead lighting to provide a daylength of $16 \mathrm{~h}$. The overhead lighting consisted of 400-W (fixtures rated for $485 \mathrm{~W}, 208 \mathrm{~V}, 2.5 \mathrm{~A}$ ) high-pressure sodium bulbs (P.L. Light Systems, Canada), resulting in a photosynthetic photon flux $(P P F)$ at canopy level of $\approx 60 \mu \mathrm{mol} \cdot \mathrm{m}^{-2} \cdot \mathrm{s}^{-1}$. The daytime temperature was maintained at $25 \pm$ $2{ }^{\circ} \mathrm{C}$, and the nighttime temperature at $18 \pm$ $2{ }^{\circ} \mathrm{C}$. Relative humidity (RH) was maintained at $65 \% \pm 5 \%$ throughout the growing season.

Tomatoes were directly seeded in pots on 11 May 1999 (Summer 1999 season) and 11 Jan. 2000 (Winter 2000 season). Two seeds of 'Sunstart', a fresh-market beefsteak variety, were planted $5 \mathrm{~cm}$ apart in the center of each pot, which contained pre-soaked, pre-fertilized soil. Unlike most cultivars used in greenhouse production, 'Sunstart' is a determinate variety, which was selected in order to limit the production season to a manageable length. Each pot received $15 \mathrm{~mL}$ ( $1 \mathrm{tbsp}$ ) of dry granular tomato fertilizer $(5 \mathrm{~N}-3.5 \mathrm{P}-8.3 \mathrm{~K}$; Purcell Vigoro Canada, Tilsonburg, Ont.), which was mixed into the top $10 \mathrm{~mm}$ of dry soil at seeding, and resulted in a roughly equivalent fertilisation rate of $110 \mathrm{~kg} \cdot \mathrm{ha}^{-1} \mathrm{~N}, 78 \mathrm{~kg} \cdot \mathrm{ha}^{-1} \mathrm{P}$, and $184 \mathrm{~kg} \cdot \mathrm{ha}^{-1} \mathrm{~K}$. Further fertilisations at the same rate occurred at 3- to 4-week intervals in both growing seasons.

In Summer 1999, $92 \%$ emergence had occurred $11 \mathrm{~d}$ after seeding (DAS), full emergence by DAS 15 and in Winter 2000 by DAS 11 and DAS 14, respectively. At the 2-leaf stage, plants were thinned to one per pot and any damaged plants replaced by extras from other treatments or by border pots. All plants received $0.5 \mathrm{~L}$ of irrigation twice a week and suckers were removed until plants reached the 4-leaf stage (DAS 53 and DAS 50). Subsequent 
suckers were allowed to grow. At this stage, just prior to the development of flower clusters, treatment plants were rearranged among blocks such that each block had plants of a similar size, i.e., one block had all the smaller plants, one had all the larger plants, and the two others the intermediate plants. Irrigation was applied based on the developmental stage of the first cluster (Table 1).

Soil characteristics. The soil consisted of a mixture of two locally available soils and some peat moss. To maintain similar soil conditions in each pot, equal volumes of dry soil mixture were placed in each pot and manually compacted until the surface of the compacted soil in each pot was $40 \mathrm{~mm}$ from the rim. The soil was then wetted regularly over a period of $3 \mathrm{~d}$ in order for it to further settle before seeding, resulting ultimately in a soil surface $50 \mathrm{~mm}$ below the edge of each pot. Soil organic matter and total carbon were measured by the wet oxidation-redox titration method of Tiessen and Moir (1993). Mean $(n=3)$ total carbon and organic matter were found to be $1.9 \%$ and $20.5 \%$ (v/v), respectively. Particle size distribution was determined by the hydrometer method. Given the high organic matter of the soil, organic matter was removed by treatment with $30 \%$ (v/v) hydrogen peroxide according to the method of Sheldric and Wang (1993). A standard hydrometer (ASTM No.1152 H) with a Boyoucos scale in $\mathrm{g} \cdot \mathrm{L}^{-1}$ was used in the analysis. The mean $(n=3)$ proportion of sand : silt : clay of the peroxide-treated soil was $71.5 \%, 16.9 \%$, and $11.6 \%$, respectively, namely a sandy loam.

Bulk density, $\rho$, of the soil was measured at the end of the growing season in each of the 36 treatment pots. In each pot, an aluminium cylinder $46.9 \mathrm{~mm}$ in diameter and $36 \mathrm{~mm}$ in height was driven into undisturbed moist soil midway between the plant stem and pot edge. The sample was dried at $105^{\circ} \mathrm{C}$ for $36 \mathrm{~h}$, then weighed. Across all treatments and blocks there was no significant difference in $\rho$, the overall mean $\pm 95 \%$ confidence interval $(n=36)$ being $0.78 \pm 0.01 \mathrm{Mg} \cdot \mathrm{m}^{-3}$.

Volumetric soil moisture content at field capacity $\left(\theta_{\mathrm{fc}}\right)$ was determined using the pressure plate method. Amatric potential $\left(\Psi_{\mathrm{m}}\right)$ of $33 \mathrm{kPa}$ was applied (James, 1988) to estimate the $\theta_{\mathrm{fc}}$, which was found to average $32 \% \mathrm{v} / \mathrm{v}(\mathrm{n}=5)$. Due to leakage of the available pressure plate apparatus, the wilting point soil moisture content $\left(\theta_{\text {wp }}\right)$ was determined according to Ibarra (1997). Three tomato plants were grown to a height of $0.3 \mathrm{~m}$ in pots identical to those used for the experimental plants. Watering was then stopped and plants allowed to wilt. When the plants had remained wilted for $3 \mathrm{~d}$ with no overnight recovery, the soil moisture content was determined using the gravimetric method. The $\theta_{\text {wp }}$ thus estimated was $11 \%(\mathrm{v} / \mathrm{v})$, a value consistent with values for similar soils (James, 1988). These values were used in computing the percent depletion of available soil water(ASW) for the water stress treatments applied. Under the $65 \%$ AW depletion treatments, the plants only received irrigation when ASW was depleted by $65 \%$ or more, that is when $\theta_{\text {soil }} \leq 0.183$; then they were irrigated back to $\theta_{\mathrm{fc}}$. Under the
$80 \%$ ASW depletion treatments, plants only received irrigation when ASW was depleted by $80 \%$ or more, i.e. when $\theta_{\text {soil }} \leq 0.152$. This mode of irrigation is illustrated in Fig. 1.

Irrigation scheduling. Daily irrigation was applied to every pot when necessary, up to the flowering stage (flowering of first cluster). As each individual plant reached the flowering stage, soil moisture status was monitored daily by time domain reflectometry (Tektronix Cable Tester, model 1502B; Tektronix, Beaverton, Ore.) and the amount of water added to each pot was calculated according to the treatment applied. In each pot three stainless steel rods $6.5 \mathrm{~mm}$ in diameter, were permanently installed, placed parallel at a uniform interval of $4.4 \mathrm{~cm}$ and to a depth of $18 \mathrm{~cm}$. The probes were held parallel by a $1.25 \mathrm{~cm}(1 / 2$ in) thick plywood block, and one terminal of the TDR was attached to the central probe, the other was split and attached to the outer probes. Topp et al. (1980) showed that, for a variety of soils, the relationship between volumetric water contents $\left(\theta_{\text {soil }}\right)$ and the dielectric constant $\left(K_{a}\right.$, unitless) is essentially independent of soil texture, porosity, and salt content. They derived a third degree polynomial relationship linking $K_{a}$ to $\theta_{\text {soil }}$; however, several subsequent studies have shown that this relationship gives a poor estimate of $\theta_{\text {soil }}$ in high organic matter soils (Zegelin et al., 1992; White et al, 1994; Or et al., 1997). Using 10 pots which were allowed to dry from field capacity to near dryness over several days, a calibration curve was developed, relating paired daily weight difference-based values of $\theta_{\text {soil }}$ and TDR-derived values of $K_{a}$. Soil moisture values derived by TDR were an average across the $18 \mathrm{~cm}$ of soil in which the rods were inserted, meaning that the roots could have been exposed to a range of stress levels. However, given the high organic matter and the not unduly high bulk density of the soil mix it was assumed that such a disparity was small, and where present, similar across a given treatment.

Then, if for example, a value of $\theta_{\text {soil }}=0.176$ was measured in a particular pot on a particular day, this value being above the $\theta_{\text {soil }}$ threshold of 0.152 for the $80 \%$ AW depletion treatment, any pot whose plant was undergoing this level of water stress treatment at its particular developmental stage would receive no irrigation on that day. This moisture level would, however, be below the $\theta_{\text {soil }}$ threshold of 0.183 for the $65 \%$ AW depletion treatment. Consequently, any pot whose plant was undergoing that level of water stress treatment at its particular developmental stage would receive irrigation sufficient to return its soil to field capacity. The irrigation requirement, IRR, in liters, given a soil volume, $\mathrm{V}_{\text {soil }}$, of $9.6 \mathrm{~L}$ would be calculated according to:

$$
\operatorname{IRR}=\left(\theta_{\mathrm{fc}}-\theta_{\text {soil }}\right) \mathrm{V}_{\text {soil }}
$$

giving a value of $1.51 \mathrm{~L}$. The NS pots and those in which the plant was not scheduled to undergo water stress (e.g., an "F" treatment plant during its first cluster fruit " $G$ " stage) were irrigated back to field capacity every day, regardless of their $\theta_{\text {soil }}$. Consequently, pots receiving no water stress had water applied daily, while those undergoing water stress received water at 2-4 day intervals (Fig. 1).

Marketable yield and quality assessment. For each mature green or riper marketable fruit of each of the treatment plants, maximum and minimum equatorial diameter and fruit height (stem scar to blossom scar) were measured with an electronic digital caliper. Mean values for each of these parameters were calculated for each plant After every harvest, marketable fruit were weighed, and after the

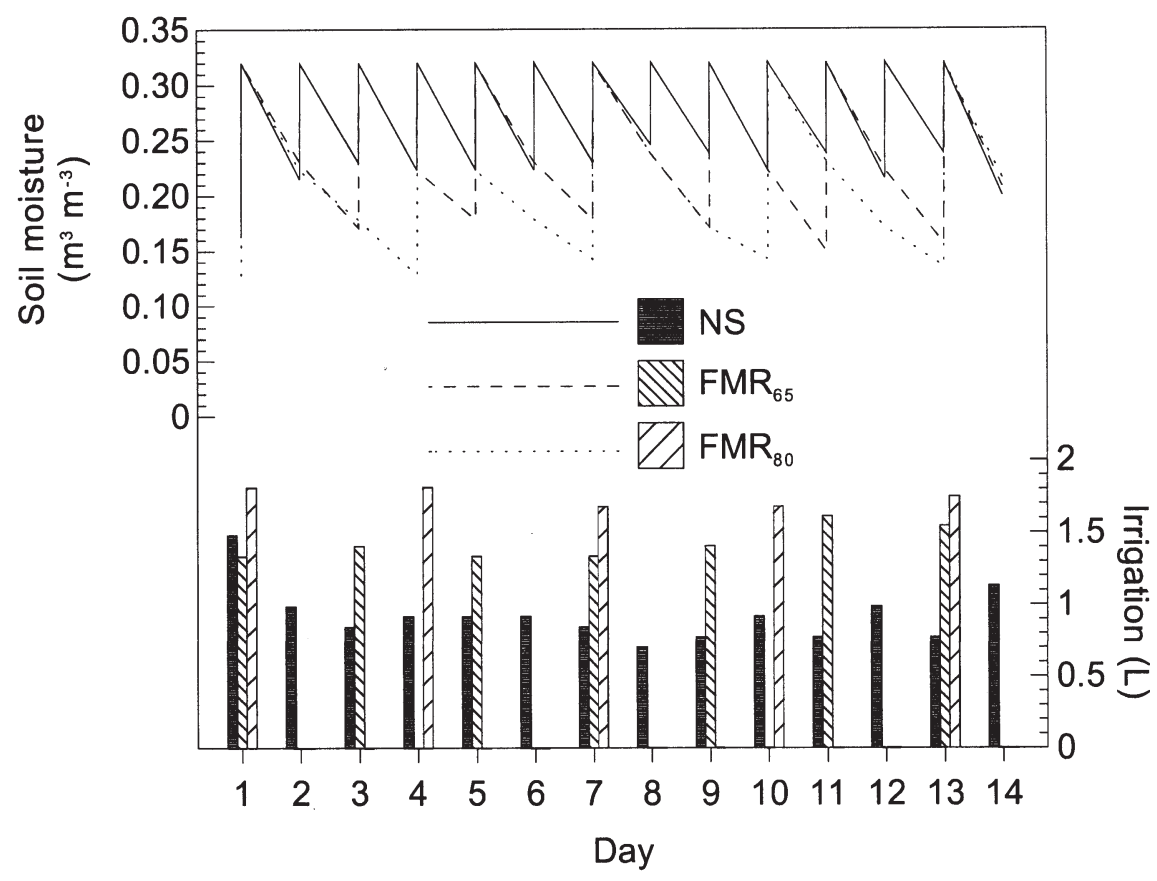

Fig. 1. Daily volumetric soil moisture content $\left(\mathrm{m}^{3} \cdot \mathrm{m}^{-3}\right)$ and irrigation volume $(\mathrm{L})$ for individual plants irrigated back to field capacity: (1) daily (NS), (2) only when available soil water is more than $65 \%$ depleted $\left(\mathrm{FGR}_{65}\right)$, or (3) only when available soil water is $>80 \%$ depleted $\left(\mathrm{FGR}_{80}\right)$. 
last harvest, totalled for each plant. Aboveground dry biomass (excluding fruit and roots) was also assessed individually for all plants. Consequently, a total of 36 values ( 4 blocks $\times$ 9 water stress treatment combinations) were obtained for each parameter. After their color was measured (see Eq. 2), marketable ripe fruit from individual plants were kept frozen at $-20{ }^{\circ} \mathrm{C}$ in individual sealed plastic bags for a period varying from 1 to 2 months (Bertin et al., 2001). The water use efficiency (WUE) was calculated as marketable yield per volume of applied water $\left(\mathrm{g} \cdot \mathrm{L}^{-1}\right)$.

Prior to freezing, the color of all individual ripe fruit or postharvest-ripened mature green fruit was measured with a Minolta CR-300 tristimulus colorimeter (Minolta, Ramsey, N.J.) equipped with an 8-mm aperture and standardized to a Minolta standard white reflector plate. Three readings of CIE 1976 L*, $a^{*}$, and $b^{*}$ values were obtained for each fruit, $\approx 1.0 \mathrm{~cm}$ from the blossom scar, and averaged. These averaged readings were converted to a tomato color index (col) originally developped for tomato juice (Yeatman et al., 1960) and shown to distinguish color among ripe tomato fruit (Hobson et al., 1983; Hobson, 1987) and among mature green fruit in storage at chilling temperatures (Dodds et al., 1991, 1996):

$$
\text { col }=\frac{200\left|\mathrm{a}^{*}\right|}{\mathrm{L}^{*} \sqrt{ } \mathrm{a}^{*}+\mathrm{b}^{* 2}}
$$

where:

$\mathrm{L}^{*}=$ lightness and ranges from 0 (black) to 100 (white)

$\mathrm{a}^{*}=\mathrm{a}$ scale ranging from green $(-100)$ to red $(+100)$

$\mathrm{b}^{*}=\mathrm{a}$ scale ranging from blue $(-100)$ to yellow $(+100)$

The col values of all the ripe fruit of a single plant were then averaged (i.e., across clusters).

All the frozen ripe fruit from a single plant were thawed at room temperature, then pooled and homogenized in a Waring blender for $1 \mathrm{~min}$. A portion of the resulting juice was filtered through 8 layers of fine weave (\#50) cheesecloth, then, under suction, through Whatman \#5 paper (Fisher Scientific, Nepean, Ont.). The $\mathrm{pH}$ was measured with a Fisher Accumet $\mathrm{pH}$ meter (model 610A; Fisher Scientific), standardized to $\mathrm{pH}=4.0$ with a reference buffer solution (American Hospital Supply Canada, Mississauga, Ont.). Percent soluble solids were determined with an Abbe-3L refractometer (Bausch and Lomb, Rochester, N.Y.), with three replicate aliquots for each sample-solution being measured and then averaged.

Data analysis. Visually obvious differences in growth and marketable yield between the two growing seasons led to an independent analysis of each season. The data for each season were treated as a $2 \times 5$ factorial combination of water stress level and timing. Statistical analysis of the data of both years was done in the SAS software, v. 6.12 (SAS Institute, 1985). The stress level and timing showed no significant interaction $(P>0.05)$ for any measured parameter, hence these factors are each presented individually. The effects of water stress timing and level were evaluated using a protected least significant difference (LSD) test $(P \leq 0.05)$. Given the single fully irrigated (NS) treatment in each block, data for both $65 \%$ AW-NS and $80 \%$ AW-NS were identical. An analysis of the non-NS treatments alone (a $2 \times 4$ factorial, not shown), showed an identical pattern of significances within factor differences.

\section{Results and Discussion}

Water stress timing had a significant effect $(P \leq 0.05)$ on all parameters measured, except pH in 1999 (Table 1). In both years, remaining dry plant biomass (roots and fruit excluded) was greatest for the NS and F treatments and least for the R and FGR treatments (Table 1), though there was no significant difference within either pair. In both years, biomass of the $G$ treatment was greater than that of the R and FGR treatments, but only in 2000 was it less than that of the NS and F treatments (Table 1). As expected, the plants under no water stress produced higher marketable yields than those under constant stress from flowering through ripening. Across both years, marketable yield by weight was significantly greater for the NS and F treatments than for the remaining treatments, and the marketable yield for the FGR treatment was significantly less than that of any other treatment. In both years, marketable yield in terms of number of fruit per plant (Table 1), was greatest for the NS treatment, significantly lower for the F, G, and $R$ treatments, and significantly lower again for the FGR treatment. The magnitude of the difference between the NS and F treatments was greater for marketable yield by number than for marketable yield by mass (35\% vs. $19 \%$ in 1999 and $13.3 \%$ and $4.7 \%$ in 2000). In both years the mean weight per fruit (not shown) was significantly greater for the F plants than the NS plants, and in 1999 greater under the F treatment than under all other treatments.

These differences are indeed reflected in the fact that for both 1999 and 2000, the largest mean maximum equatorial diameter, minimum equatorial diameter, and stem to blossom scar fruit height were recorded for the $\mathrm{F}$ treatment (Table 1), compared to all other treatments, though these differences were not always significant. While in 2000 the FGR fruit were smaller than all other fruit, in 1999 they were only significantly smaller than the NS and F fruit. Thus, overall, plant dry biomass and fresh fruit weight were greatest for the NS and F treatments, which did not differ significantly amongst themselves except in the case of fresh fruit mass in 1999, where F was $19 \%$ less than NS. These parameters were lowest for the FGR treatment and intermediate to low for the $\mathrm{G}$ and $\mathrm{R}$ treatments. A similar pattern was observed with respect to marketable yield by number, except that the NS-F difference was consistently significant, so while F plants produced fewer fruit than NS plants, the F fruits were larger and heavier than those from NS plants, ultimately resulting in similar marketable yields by weight.

Marketable yield and quality parameters were determined for all clusters combined, so that any specific effect of water stress on marketable yield of the first cluster was not assessed. While a comparison of marketable yield and quality parameters between clusters could have yielded useful insights, it was not done because (1) fruit of a number of first clusters, under certain treatments, were entirely lost to blossom end rot (BER, see below), leaving no basis for comparison of marketable fruit, and (2) as plants were not suckered beyond the 4-leaf stage, it was not possible to distinguish flowering clusters occuring simultaneously on different suckers, on the main stem, or both, on a phenological basis.

A number of studies from Salter (1954) to Branthome and Plé (1987) have shown the greatest marketable yield response to irrigation to occur at the flowering and fruit set stage. Rudich et al. (1977) grew tomatoes with drip irrigation under arid field conditions. He applied or withheld irrigation at five developmental stages: (1) germination-emergence; (2) vegetative; (3) flowering of first cluster to first mature green fruit; (4) mature green to breaker stage ( $20 \%$ color) of the first cluster; and (5) breaker to full ripe on the first cluster. They showed the "flowering to mature green" stage to be the most susceptible to improvement of marketable yield by irrigation. Irrigation during the "mature green to breaker" stage also improved marketable yield, but unlike the "flowering to mature green stage" led to lowered soluble solids, acidity, color and ascorbic acid content. In our case the least reduction of marketable yield under water stress, relative to full irrigation, occurred for plants where the stress was imposed during the flowering and fruit set $(F)$ period of the first cluster. However, our study, unlike Rudich's (1977), separated the flowering to mature green fruit stage into two stages: F and fruit growth $(\mathrm{G})$. There was a general, but not always significant trend of poorer marketable yield, plant biomass and fruit size under the $G$ treatment compared to the $\mathrm{F}$ treatment. This would suggest that the sensitivity to water stress occurs predominantly during fruit growth rather than flowering and fruit set.

However, the high marketable yield by weight for the $\mathrm{F}$ treatment could be related to the removal of fruit with BER, which occurred as soon as they were detected. This would have allowed the nutrients and metabolites the plants would have appropriated to these fruit to instead be allocated to the needs of subsequent clusters and vegetative growth. This in turn could produce greater source areas for fruit of subsequent clusters, allowing them to grow larger. Under all treatments, the vast majority of the BER fruit occurred on the first cluster $(>90 \%)$. Such a predominance of BER in the first cluster over later ones was also observed by Franco et al. (1999). The greater incidence of BER under water stress has long been reported (Güssow, 1912; Reid et al., 1996). The number of BER fruit per plant varied widely, but in both years there was a tendency $(0.05<P \leq 0.10)$ 
Soll Management, Fertilization, \& Irrigation

Table 1. Effect of the timing of the water stress on tomato marketable yield and quality parameters in the Summer 1999 and Winter 2000 growing seasons. Values averaged over the 65 and $80 \%$ available water treatments.

\begin{tabular}{|c|c|c|c|c|c|c|c|c|c|c|c|c|c|}
\hline \multirow[b]{2}{*}{ Season } & \multicolumn{2}{|c|}{ Timing of water stress ${ }^{2}$} & \multirow{2}{*}{$\begin{array}{c}\text { Blossom } \\
\text { end rot } \\
\text { (No./plant) }\end{array}$} & \multicolumn{4}{|c|}{ Marketable production } & \multicolumn{3}{|c|}{ Fruit dimensions $(\mathrm{mm})^{\mathrm{t}}$} & \multicolumn{3}{|c|}{ Fruit quality ${ }^{s}$} \\
\hline & Stage & DAS & & $\begin{array}{c}\text { Yield }^{\mathrm{x}} \\
\text { (No./plant) }\end{array}$ & $\begin{array}{c}\text { Yield }^{\mathrm{w}} \\
\text { (kg/plant) }\end{array}$ & $\begin{array}{c}\text { Plant biomass } \\
\text { (kg/plant) }\end{array}$ & $\begin{array}{c}\mathrm{WUE}^{\mathrm{u}} \\
(\mathrm{g} / \mathrm{L})\end{array}$ & $\begin{array}{l}\text { Max. eq. } \\
\text { diam. }\end{array}$ & $\begin{array}{l}\text { Min. eq. } \\
\text { diam. }\end{array}$ & Height & $\begin{array}{c}\text { Soluble solids } \\
\left({ }^{\circ} \text { Brix }\right)\end{array}$ & $\mathrm{pH}$ & $\mathrm{col}$ \\
\hline Summer & NS & & $2.3 \mathrm{~d}$ & $23 \mathrm{a}$ & $1.78 \mathrm{a}$ & $0.165 \mathrm{a}$ & $27.6 \mathrm{a}$ & $53.6 \mathrm{~b}$ & $50.5 \mathrm{~b}$ & $46.5 \mathrm{~b}$ & $6.71 \mathrm{c}$ & $4.52 \mathrm{a}$ & $37.5 \mathrm{~b}$ \\
\hline \multirow[t]{4}{*}{1999} & $\mathrm{~F}$ & $66-83$ & $2.7 \mathrm{~cd}$ & $15 \mathrm{~b}$ & $1.45 \mathrm{~b}$ & $0.167 \mathrm{a}$ & $21.0 \mathrm{~b}$ & $61.6 \mathrm{a}$ & $54.0 \mathrm{a}$ & $52.3 \mathrm{a}$ & $6.80 \mathrm{c}$ & $4.47 \mathrm{a}$ & $37.7 \mathrm{~b}$ \\
\hline & G & $84-119$ & $4.2 \mathrm{ab}$ & $16 \mathrm{~b}$ & $1.07 \mathrm{c}$ & $0.158 \mathrm{a}$ & $16.7 \mathrm{c}$ & $51.7 \mathrm{bc}$ & $48.4 \mathrm{bc}$ & $45.6 \mathrm{bc}$ & $7.78 \mathrm{~b}$ & $4.61 \mathrm{a}$ & $39.1 \mathrm{a}$ \\
\hline & $\mathrm{R}$ & $120-139$ & $3.6 \mathrm{a}$ & $15 \mathrm{~b}$ & $1.22 \mathrm{c}$ & $0.131 \mathrm{~b}$ & $20.9 \mathrm{~b}$ & $48.2 \mathrm{c}$ & $45.8 \mathrm{c}$ & $42.5 \mathrm{c}$ & $8.91 \mathrm{a}$ & $4.52 \mathrm{a}$ & $39.4 \mathrm{a}$ \\
\hline & FGR & 66-283 & $4.8 \mathrm{a}$ & $11 \mathrm{c}$ & $0.78 \mathrm{~d}$ & $0.117 \mathrm{~b}$ & $13.8 \mathrm{c}$ & $49.8 \mathrm{bc}$ & $46.2 \mathrm{bc}$ & $42.4 \mathrm{c}$ & $8.50 \mathrm{a}$ & $4.50 \mathrm{a}$ & $39.5 \mathrm{a}$ \\
\hline Winter & NS & & $2.6 \mathrm{c}$ & $15 \mathrm{a}$ & $1.34 \mathrm{a}$ & $0.143 \mathrm{a}$ & $26.4 \mathrm{a}$ & $54.6 \mathrm{ab}$ & $44.7 \mathrm{a}$ & $44.7 \mathrm{a}$ & $7.17 \mathrm{~b}$ & $4.35 \mathrm{a}$ & $33.5 \mathrm{~b}$ \\
\hline \multirow[t]{4}{*}{2000} & $\mathrm{~F}$ & $71-88$ & $2.8 \mathrm{c}$ & $13 \mathrm{~b}$ & $1.40 \mathrm{a}$ & $0.141 \mathrm{a}$ & $29.0 \mathrm{a}$ & $56.7 \mathrm{a}$ & $51.4 \mathrm{a}$ & $45.2 \mathrm{a}$ & $7.71 \mathrm{~b}$ & $4.20 \mathrm{~b}$ & $32.7 \mathrm{~b}$ \\
\hline & G & 89-116 & $3.9 \mathrm{ab}$ & $10 \mathrm{c}$ & $0.98 \mathrm{~b}$ & $0.128 \mathrm{~b}$ & $26.1 \mathrm{a}$ & $56.0 \mathrm{ab}$ & $51.0 \mathrm{a}$ & $45.0 \mathrm{a}$ & $8.94 \mathrm{a}$ & $4.24 \mathrm{ab}$ & $37.9 \mathrm{a}$ \\
\hline & $\mathrm{R}$ & $117-136$ & $3.3 \mathrm{bc}$ & $11 \mathrm{~b}$ & $1.00 \mathrm{~b}$ & $0.115 \mathrm{c}$ & $26.0 \mathrm{a}$ & $50.2 \mathrm{~b}$ & $46.8 \mathrm{a}$ & $41.3 \mathrm{ab}$ & $8.84 \mathrm{a}$ & $42.9 \mathrm{ab}$ & $37.4 \mathrm{a}$ \\
\hline & FGR & $71-182$ & $4.3 \mathrm{a}$ & $8 \mathrm{~d}$ & $0.49 \mathrm{c}$ & $0.113 \mathrm{c}$ & $18.5 \mathrm{~b}$ & $42.5 \mathrm{c}$ & 40.3 & $37.1 \mathrm{~b}$ & $9.18 \mathrm{a}$ & $4.19 \mathrm{~b}$ & $38.7 \mathrm{a}$ \\
\hline
\end{tabular}

${ }^{2} \mathrm{NS}=$ never subjected to stress; $\mathrm{F}$ = stressed only during flowering/fruit set; $\mathrm{G}=$ stressed only during fruit growth; $\mathrm{R}=$ stressed only during fruit ripening; FGR $=$ stressed during flowering/fruit set, fruit growth and fruit ripening. DAS = mean days after seeding

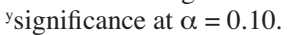

${ }^{x}$ Excludes fruit with blossom end rot.

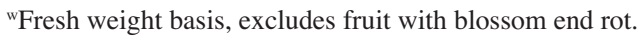

'Dry weight basis

"Water use efficiency or marketable yield per water applied.

'Max. Eq. Diam. and Min. Eq. Diam are the mean maximum and minimum equatorial diameters of the fruit, while height is measured from the blossom scar to the stem scar.

${ }^{\mathrm{s}} \mathrm{Col}$ is the tomato color index, Eq. 2

Means within columns within year followed by different letters are significantly different at $P \leq 0.05$ (protected least significant difference test)

for the mean number of BER fruit under the single-stage water-stressed treatments to be greater, particularly for the $\mathrm{G}$ treatment, than under the full irrigation NS treatment (Table 1). In both seasons more BER tended $(0.05<P$ $\leq 0.10$ ) to develop under the $80 \%$ ASW treatment (4.2-4.5 fruit/plant) than under the $65 \%$ ASW treatment (2.6 fruit/plant). No correlation existed between number of BER fruit on a plant and its subsequent total marketable yield (data not shown). Reid et al. (1996) showed that while an unirrigated field crop of tomatoes showed a significantly greater incidence of BER than an irrigated one, marketable yield, fruit size and soluble solids were not affected. Consequently it is clear from both his work and ours that a heightened incidence of BER does not necessarily result in lowered marketable yields.

In both years, water use efficiency was lowest for the FGR treatment, $56 \%$ less than for the NS treatment (Table 1), indicating that while water was saved, the resultant marketable yield loss was proportionally greater. One might have expected that restricted irrigation during only a portion of the season might improve WUE; however, in both years WUE for the NS treatment was among the highest. In 1999, the F treatment showed a WUE significantly lower (24\%) than that of the NS treatment, equivalent to that for the R treatment, and significantly greater (52\%) than that of the FGR treatment. In 2000, however, the WUE under the $\mathrm{F}$ treatment was not significantly different from that under the NS treatment, but significantly greater (41\%) than under the FGR treatment. This would indicate that very little if any WUE is lost under the F treatment, compared to the NS treatment.

In terms of fruit quality, NS and F treatments yielded marketable fruit with less soluble solids than their G, R, or FGR counterparts (Table $1)$. For both years, the G, R, and FGR treatments showed soluble solids contents $16 \%$ to 28\% higher than NS fruit. In 1999 and 2000, soluble solids in the $\mathrm{F}$ fruit were significantly lower (20\% and $16 \%$, respectively) than those of FGR fruit. Similarly, Moore et al. (1958) and May (1993) have shown higher soluble solids under water stress, which is attributable to the restricted water uptake into the fruit under stress, lower percentage water in the fruit, and consequently higher solute concentration.

In terms of $\mathrm{pH}$ (Table 1), no clear pattern emerged, except perhaps that NS fruit tended to have higher $\mathrm{pHs}$, and FGR and $\mathrm{F}$ fruit lower pHs. Similarly, studies of the effect of water stress on tomato fruit $\mathrm{pH}$ have been inconsistent. For example, Giardini et al. (1988) and Tan (1995) found a decrease in fruit $\mathrm{pH}$ under stress, while Sanders et al. (1989) found the opposite, and Alvino et al. (1988) found no effect.

In both years, the color index was significantly lower for the NS and F red ripe fruit than the G, R, or FGR fruit. The color index which ranges from $\approx 18$ for mature green fruit to between 35 and 40 for red ripe to overripe fruit, shows the NS and F fruit to be less darkly colored on average, than G, R, or FGR fruit. Since fruit were harvested red ripe during the season and at the last harvest either directly harvested or allowed to ripen to red ripe from mature green, it appears unlikely that this difference could be attributed to a more advanced ripening in the $\mathrm{G}, \mathrm{R}$, and FGR fruit, than in the NS and F fruit. This difference was not noted visually and would thus probably not be an issue in terms of consumer preference.

Except for marketable yield by number (fruits/plant) in the Winter 2000 season, which was lower at $80 \%$ ASW depletion than at $65 \%$ ASW depletion $(P \leq 0.05)$, the level of water stress had no significant effect on any marketable yield or quality parameter measured. Plants stressed at all stages (FGR) at either stress level had less marketable yield by number, by weight, and had individual fruit that were smaller and bore less weight than those from fully irrigated plants. Other studies have shown differences in marketable yield between different levels of water stress. Losada and Rincón (1994) showed tomato plants under daily irrigation at 0.9 of evapotranspirative demand (ET) yielded $42 \%$ more than those under $0.5 \mathrm{ET}_{\mathrm{c}}(P \leq 0.05)$. The 0.9 and $0.5 \mathrm{ET}_{\mathrm{c}}$ treatments yielded $28 \%$ and $58 \%$ less, respectively than a $1.3 \mathrm{ET}$ irrigation treatment. May (1993) showed significant differences in tomato fruit marketable yield between irrigation occuring when the soil reached $20 \%, 40 \%$, or $60 \%$ of available water. Similarly, Ramadan and Nwokeocha (2000) showed that tomatoes irrigated when soil moisture tension reached $-30 \mathrm{kPa}$ yielded $20 \%$ more by number, $29 \%$ more by weight, and were $22 \%$ larger than those irrigated when the soil moisture tension reached $-60 \mathrm{kPa}(P \leq 0.05)$. As with Losada and Rincón, full irrigation gave better marketable yield than either of the limited irrigation treatments. They suggested that as the soil dried, water absorption by roots fell below transpiration leading to an internal water deficit. This in turn would adversely affect photosynthesis, lead to reduced leaf area in newly formed vegetative tissues and small cells and intracellular volumes in fruit, which would limit fruit moisture accumulation. In the case of our study, the lack of differences may be attributable to the levels of water stress imposed both being somewhat greater than those employed in the studies cited, so that differences were obscured by the severity of both stress levels.

\section{Conclusion}

Imposing water stress during fruit growth and fruit ripening stages or from flowering onward reduced marketable yield and WUE, and increased fruit soluble solids and color relative to the fully irrigated treatement. However, water stress imposed at flowering, while it reduced marketable yield and WUE in 1999, had little or the opposite effect in 2000. The application of water stress during flowering had no significant effect on any fruit quality 
parameters. In the current study, the timing of the water stress was much more important in terms of marketable yield and quality than the magnitude of the stress.

\section{Literature Cited}

Alvino, A., R. d'Andria, and G. Zerbi. 1988. Fruit ripening of different tomato cultivars as influenced by irrigation regime and time of harvesting. Acta Hort. 228:137-141.

Bertin, N., M. Buret, and C. Gary. 2001. Insights into the formation of tomato quality during fruit development. J. Hort. Sci. Technol. 76:786-792.

Branthome, X. and Y. Plé. 1987. Irrigation for mechanized harvest of processing tomatoes. Acta Hort. 200:165-172.

Dodds, G.T, J.W. Brown, and P.M. Ludford. 1991. Surface color changes of tomato and other solanaceous fruit during chilling. J. Amer. Soc.Hort. Sci. 116:482-490.

Dodds, G.T., L. Trenholm, and C.A. Madramootoo. 1996. Effects of watertable and fertilizer management on susceptibility of tomato fruit to chilling injury. J. Amer. Soc. Hort. Sci. 121:525-530.

Doorenbos, J. and A.H. Kassam. 1979. Yield response to water. FAO Irrigation and Drainage Paper 33:157-160.

Franco, J.A., P.J. Pérez-Saura, J.A. Fernández, M. Parra, and A.L. García. 1999. Effect of two irrigation rates on yield, incidence of blossom-end rot, mineral content and free amino acid levels in tomato cultivated under drip irrigation using saline water. J. Hort. Sci. Technol. 74:430-435.

Giardini, L., R. Giovanardi, and M. Borin. 1988. Water consumption and yield response of tomato in relation to water availability at different soil depth [sic]. Acta Hort. 228:119-126.

Güssow, H.T. 1912. Report of the Dominion botanist. Canada Expt. Farms Rpt. (1912), Ottawa, Govt. of Canada, p. 206-207.

Heermann, D.F., D.L. Martin, R.D. Jackson, and E.C. Stegman. 1990. Irrigation scheduling controls and techniques. Amer. Soc. Agron. Monogr. 30: 509-535. Madison, Wisc.

Hobson, G.E. 1987. Low-temperature injury and the storage of ripening tomatoes. J. Hort. Sci. 62:55-62.

Hobson, G.E., P. Adams, and T.J. Dixon. 1983. Assessing the color of tomato fruit during ripening. J. Sci. Food Agr. 34:286-292.

Hoffman, G.J., T.A. Howell, and K.H. Solomon. 1990. Management of farm irrigation systems. p. 1-10. In: G.J. Hoffman, T.A. Howell, and K.H. Solomon (eds.). ASAE Monogr. ASAE. St. Joseph, Mich.

Ibarra, S. 1997. Soil moisture and tensiometer measurements made to assist the management of supplementary irrigation of maize in eastern Ontario. M.Sc. thesis. Dept of Agr. and Biosystems Eng., McGill Univ., Montreal Canada.

James, L. 1988. Principles of farm irrigation system design. Wiley, New York. p. 4

Kirda, C. 2002. Deficit irrigation scheduling based on plant growth stages showing water stress tolerance, p. 3-10. In: L.K. Heng, P. Moutonnet, and M. Smith (compilers). Deficit irrigation practices-FAO Water Rpt. 22. FAO.Rome.

Lorrain, P. and D.R. Corson, 1970. Electromagnetic Fields and Waves. 2nd ed., W.H. Freeman, New York.

Losada, H.P. and R. Rincón. 1994. Influence of the crop water status on fruit setting and final fruit number in the processing tomato crop. Acta Hort. 376:333-336.

May, D.M. 1993. Moisture stress to maximize processing tomato yield and quality. Acta Hort. 335:547-552.

Mitchell, J.P.C., S.R., Shennam, and D.M. May. 1991. Tomato fruit yield and quality under water deficit and salinity. J. Amer. Soc. Hort. Sci. 116:215-221.

Moore, J.N., A.A. Kattan, and J.W. Fleming. 1958. Effect of supplemental irrigation, spacing and fertility on yield and quality of processing tomatoes. Proc. Amer. Soc. Hort. Sci. 71: 356-368.

Or, D., B. Fisher, R.A. Hubscher, and J. Wraith. 1997. WinTDR 98 V. 4.0-Users guide. Utah State Univ. Soil Physics Group, Logan, Utah.

Pill, W.G. and V.N. Lambeth. 1980. Effect of soil water regime and nitrogen form on blossom-end rot. Yield relations and elemental composition of tomato. J. Amer. Soc. Hort. Sci. 105:730-735

Postel, S.L. 2000. Entering an era of water scarcity: The challenges ahead. Ecol. Appl. 10: 941-948.

Rahman, S.M L., E. Nawata, and T. Sakuratani. 1999. Effect of water stress on growth, yield and eco-physiological responses of four ( Lycopersicon esculentum Mill) tomato cultivars. J. Jpn. Soc. Hort. Sci. 68:499-504.

Ramadan,A.A. and C.U.Nwokeocha. 2000. Effects of furrow irrigation methods, mulching and soil water suction on the growth, yield and water use efficiency of tomato in the Nigerian savanna.
Agr. Water Mgt. 45:317-330.

Reid, J.B., D. Winfield, I. Sorenson, and A.J. Kale. 1996. Water deficit, root demography, and the causes of internal blackening in field-grown tomatoes (Lycopersicon esculentum Mill.). Ann. Appl. Biol. 129:137-149.

Salter, P.J. 1954. The effects of different water regimes on the growth of plants under glass. I. Experiments with tomatoes (Lycopersicon esculentum Mill.). J. Hort. Sci. 29:258-268.

Sanders, D.C., T.A. Howell, M.M.S. Hile, L. Hodges, D. Meek, and C.J. Phene. 1989. Yield and quality of processing tomatoes in response to irrigation rate and schedule. J. Amer. Soc. Hort. Sci. 114: 904-908.

SAS Institute. 1985. SAS user's guide: Statistics. 5th ed. SAS Inst., Cary, N.C.

Sheldric, B.H. and C. Wang. 1993. Particle size distribution. p. 499-511. In: M.R. Carter (ed.). Soil sampling and methods of analysis. Lewis Publishers, London.

Tan, C.S. 1995. Effect of drip and sprinkle irrigation on yield and quality of five tomato cultivars in southwestern Ontario. Can. J. Plant Sci. 75: 225-230.

Tiessen, H. and J.O. Moir. 1993. Total organic carbon. p. 187-199. In: M.R. Carter (ed.). Soil sampling and methods of analysis. Lewis Publishers, London.

Topp, G.C., J.L. Davis, and A.P. Annan, 1980. Electromagnetic determination of soil water content: measurement in coaxial transmission lines. Water Resour. Res. 16:574-582.

White, I, S.J. Zegelin, G.C. Topp, and A. Fish. 1994. Effect of bulk electrical conductivity on TDR measurement of water content in porous media, p. 294-308. In: Symposium and workshop on time domain reflectometry in environmental infrastructure and mining applications, Northwestern Univ., Evanston, Ill., 17-19 Sept. 1994. Washington, D.C.: U.S. Bureau of Mines.

Yeatman, J.N., A.P. Sidwell, and K.H. Norris. 1960. Derivation of a new formula for computing raw tomato juice color from objective color measurements. Food Technol. 14:16-20

Zegelin, S.J., I. White, and G.F. Russell. 1992. A critique of the time domain reflectometry technique for determining field soil-water content, p. 187-208. In: G.C. Topp, W.D. Reynolds, and R.E. Green (eds.). Advances in measurements of soil physical properties: Bringing theory into practice. Soil Sci. Soc. of Amer., Madison, Wisc. 